\title{
Debris-Flow Hazards within the Appalachian Mountains of the Eastern United States
}

Tropical storms, including hurricanes, often inflict major damage to property and disrupt the lives of people living in coastal areas of the Eastern United States. These storms also are capable of generating catastrophic landslides within the steep slopes of the Appalachian Mountains. Heavy rainfall from hurricanes, cloudbursts, and thunderstorms can generate rapidly moving debris flows that are among the most dangerous and damaging type of landslides. This fact sheet explores the nature and occurrence of debris flows in the central and southern Appalachian Mountains, which extend from central Pennsylvania to northern Alabama.

\section{Geology and Climate Contribute to Debris Flows}

Debris flows are considered one of the most dangerous forms of landslides, which is a general term covering a wide variety of mass-movement landforms and processes involving the downslope transport of soil and rock material en masse. A debris flow is a moving mass of fragmented rock and soil in which more than half of the particles are greater than sand size. Because a debris flow moves rapidly and with great force, it is capable of destroying almost everything in its path. Debris flows are most frequently generated on steep slopes during heavy rainfall, and often travel along preexisting drainages and streams. The soils and poorly consolidated material on these slopes may become saturated during rainfall, lose coherence, and begin moving downslope in a flowing stream, drawing in and transporting additional soil and rock as the flow rapidly moves through the drainage network.

The central and southern Appalachian Mountains are comprised of three physiographic provinces that have had many historic debris flows; the provinces are, from east to west, the Blue Ridge, the Valley and Ridge, and the Appalachian Plateau. The Blue Ridge province is underlain by igneous and sedimentary rocks that have undergone structural transformation. Some of the highest peaks in the Appalachian Mountains are in this province. The Valley and Ridge province is underlain by folded sedimentary rocks, typically with inclined sandstone strata beneath ridges. The Appalachian Plateau province is underlain by nearly flat-lying sedimentary rocks. Debris flows have occurred in all of these provinces. When considered on a regional scale, rainfall and the steepness of a slope are important parameters governing debris-flow distribution, in addition to rock type and structure. Extreme rainfall events are the most likely trigger.

Fifty-one debris flows that occurred in the Appalachian region between 1844 and 1985 were documented by Michael Clark (Clark, 1987). Figure 1 shows the distribution of these flows (also referred to as historical landslide events). Many of these events occurred in isolated and rural areas; therefore, the

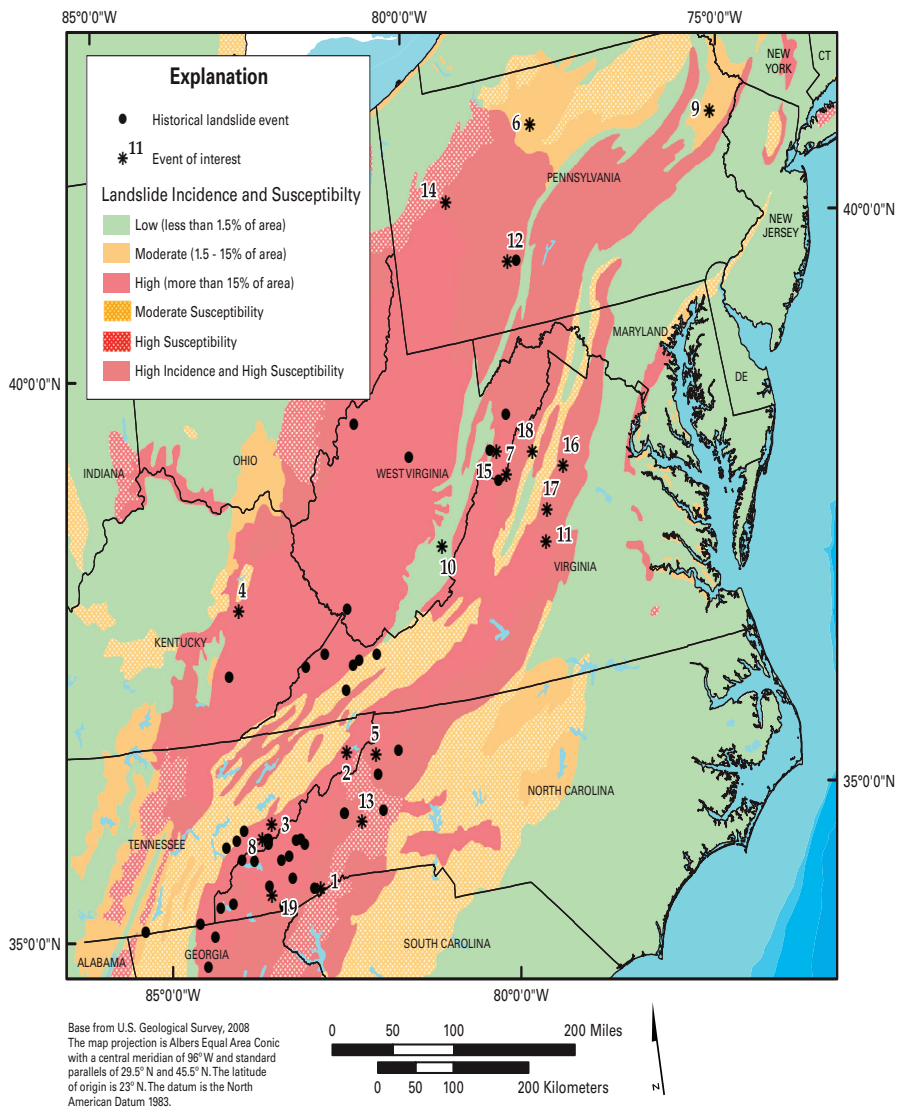

Figure 1. Distribution of debris flows within the Appalachian Mountains of the Eastern United States (Sources: Clark, 1987; Radbruch-Hall and others, 1982).

data on the number of debris flows, the area affected, or the associated rainfall are lacking. Published reports about these events have been reviewed by the U.S. Geological Survey, plus four additional documented events that have occurred since 1987. Nineteen examples of debris flows are listed in table 1, including the date, location, number of reported flows, type of storm, total rainfall, and rainfall duration. These 19 events are depicted in figure 1 with small asterisks. The debris flows from Clark (1987) and from table 1 are plotted in figure 1. Most of the events fall into areas of high incidence and high susceptibility (red), but several events are in areas of much less susceptibility. The map is useful in depicting regional trends, but should not be used to predict future occurrences.

\section{Some Well-Documented Debris Flows}

The most devastating debris flow listed in table 1 occurred during the night of August 19-20, 1969, in Nelson County, Va. 
Table 1. Examples of historical rainfall-induced debris flows within Appalachian Mountains of the Eastern United States.

[ , approximately; >, more than]

\begin{tabular}{|c|c|c|c|c|c|c|}
\hline $\begin{array}{l}\text { Location } \\
\text { number on } \\
\text { figure } 1\end{array}$ & $\begin{array}{c}\text { Rainfall } \\
\text { total, in } \\
\text { millimeters }\end{array}$ & $\begin{array}{l}\text { Duration of } \\
\text { most severe } \\
\text { rainfall }\end{array}$ & Type of rain event & $\begin{array}{l}\text { Number of } \\
\text { reported debris } \\
\text { flows }\end{array}$ & $\begin{array}{l}\text { Dates of debris } \\
\text { flows } \\
\text { (month/day/year) }\end{array}$ & General location \\
\hline 1 & 564 & 24 hours & Hurricane & 45 & $7 / 15-16 / 1916$ & Transylvania County, N.C. \\
\hline 2 & 380 & 2 days & Thunderstorm & $\sim 100$ & $6 / 13 / 1924$ & Carter County, Tenn. \\
\hline 3 & 305 & 4 hours & Cloudburst & $>100$ & $8 / 4-5 / 1938$ & Webb Mountain, Tenn. \\
\hline 4 & 508 & 2 days & Thunderstorm & $\begin{array}{l}4 \text { on photo, } \\
\text { but total not } \\
\text { reported }\end{array}$ & $7 / 4-5 / 1939$ & $\begin{array}{l}\text { Wolfe and Breathitt County, eastern } \\
\text { Kentucky }\end{array}$ \\
\hline 5 & 254 & 6 hours & Hurricane & 763 & $8 / 10-17 / 1940$ & Watauga County, N.C. \\
\hline 6 & 782 & 4.5 hours & Thunderstorm & Numerous & $7 / 18 / 1942$ & $\begin{array}{l}\text { Elk, McKean, Potter, and Cameron } \\
\text { Counties, north-central Pennsyl- } \\
\text { vania }\end{array}$ \\
\hline 7 & 400 & 1 day & Cloudburst & 466 & $6 / 17-18 / 1949$ & $\begin{array}{l}\text { Augusta and Rockingham Counties, } \\
\text { Va., and Highland County, W. Va. }\end{array}$ \\
\hline 8 & 116 & 1 hour & Cloudburst & 100 & $9 / 1 / 1951$ & $\begin{array}{l}\text { Mount Le Conte, Great Smoky } \\
\text { Mountains National Park, Tenn. }\end{array}$ \\
\hline 9 & 254 & 2 days & Hurricane Diane & 4 & $8 / 18-19 / 1955$ & $\begin{array}{l}\text { Brodhead Creek, northeastern Penn- } \\
\text { sylvania }\end{array}$ \\
\hline 10 & 635 & 8 hours & Hurricane Camille & 1584 & $\begin{array}{l}8 / 19-20 / 1969 \text { and } \\
9 / 5-6 / 1969\end{array}$ & $\begin{array}{l}\text { Spring Creek, Greenbrier County, } \\
\text { W. Va. }\end{array}$ \\
\hline 11 & $710-800$ & 8 hours & Hurricane Camille & 3793 & $8 / 19-20 / 1969$ & Nelson County, Va. \\
\hline 12 & 300 & 9 hours & $\begin{array}{l}\text { Thunderstorm or cloud- } \\
\text { burst }\end{array}$ & Several hundred & 7/19-20/1977 & $\begin{array}{l}\text { Johnstown area, western Pennsyl- } \\
\text { vania }\end{array}$ \\
\hline 13 & 320 & 5 days & Storm & 24 & $11 / 6-7 / 1977$ & $\begin{array}{l}\text { Asheville-Statesville, Transylvania } \\
\text { County, N.C. }\end{array}$ \\
\hline 14 & 115 & 14 days & Thunderstorm & 62 & $8 / 14 / 1980$ & $\begin{array}{l}\text { East Brady, along Allegheny River, } \\
\text { northern Pennsylvania }\end{array}$ \\
\hline 15 & 350 & 3 days & Hurricane Juan & 3,000 & $9 / 3-5 / 1985$ & $\begin{array}{l}\text { Pendleton County, W. Va., and High- } \\
\text { land County, Va. }\end{array}$ \\
\hline 16 & 770 & $14 \mathrm{hrs}$ & Storm & 629 & $6 / 27 / 1995$ & Madison County, Va. \\
\hline 17 & 635 & 1 day & Storm & 61 & $6 / 27 / 1995$ & Albemarle County, Va. \\
\hline 18 & 513 & 1 day & Hurricane Isabel & 6 & $9 / 18-19 / 2003$ & Shenandoah Valley, Va. \\
\hline 19 & 636 & 11 days & $\begin{array}{l}\text { Hurricanes Frances } \\
\text { and Ivan }\end{array}$ & 155 & $9 / 7-17 / 2004$ & Macon County, N.C. \\
\hline
\end{tabular}

Hurricane Camille, having caused great damage along the Gulf Coast in Mississippi, moved northeast into Virginia as a tropical depression and stalled in central Virginia. The result was a heavy rainfall of at least 710 millimeters (mm) (28 inches (in)) within an 8-hour period during the night. Approximately 3,800 debris flows and associated flooding resulted, destroying houses and killing 150 people within Nelson County.

During the more recent Hurricane Ivan, on September 16, 2004, in Macon County, N.C., soil and rock material detached from the upper slopes of Fish Hawk Mountain and moved as a debris flow 3.6 kilometers (2.2 miles) downslope along Peeks Creek to the Cullasaja River, causing 5 deaths and 2 injuries, and destroying 16 buildings (figs. $2 A$ and $B$ ).

On June 27, 1995, a small but violent summer storm dropped 250 to $770 \mathrm{~mm}$ (30 in) of rain over a 16-hour period on a small area in rural Madison County, Va., resulting in at least 629 highly destructive debris flows. The storm, which occurred during the day in a moderately populated area, was tracked by the National Weather Service using Doppler radar. The landslide and debris-flow area resulting from this storm was extensively photographed and examined in the field. The data that were obtained can serve as a model to help predict the potential for similar events within the Appalachian Mountains.
Figure 3 shows an area affected by the June 1995 storm near Graves Mill, Madison County, Va. Debris flows are shown in dark shading and areas of flooding are indicated by lighter shading. Rainfall in this area exceeded $700 \mathrm{~mm}$ (27 in). During the 1995 event, the majority of debris flows occurred within a larger region where rainfall exceeded $500 \mathrm{~mm}$ (20 in).

Figure 4 shows the cumulative rainfall for the Madison County event at several locations affected by the 1995 storm. A few of the debris flows were witnessed, and their times recorded; these observed debris flows are shown as letters A-M. What is striking about these data is that the debris flows were generated during the 3 -hour period of rapid increase in precipitation, suggesting that the rate of rainfall is most critical, and even more critical than total storm rainfall. The high rate of rainfall is required to sufficiently wet the soil so that the internal pressure of contained water breaks down the coherence of the soil particles, allowing the entire saturated mass to flow downslope.

\section{Forecasting Debris Flows}

Prediction of debris flows based on rainfall thresholds remains highly problematic. For example, the relation that prolonged precipitation has on landslides by wetting the soil before 

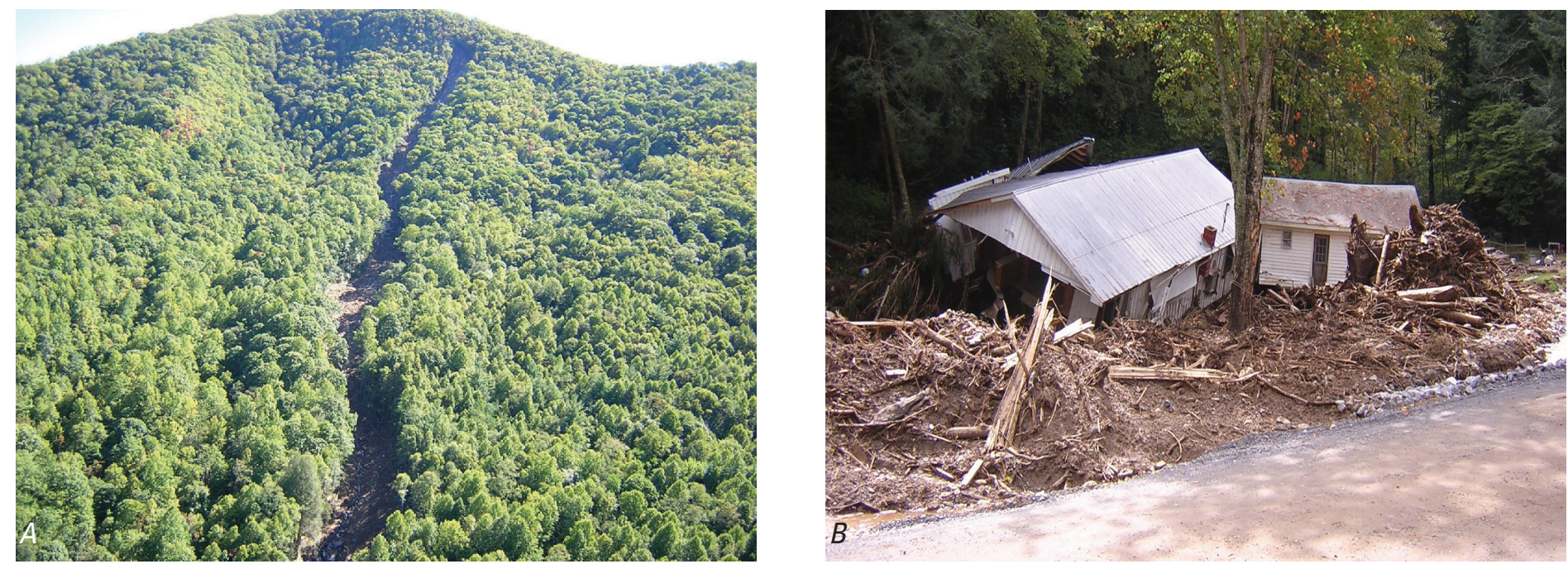

Figure 2. A. Hurricane Ivan triggered this large and lengthy Peeks Creek landslide and debris flow in Macon County, N.C., on September 16, 2004. B. Buildings destroyed by the landslide and debris flow at Peeks Creek, N.C., during Hurricane Ivan, September 16, 2004. Photographs by Richard Wooten, North Carolina Geological Survey.

a major storm is entirely unknown. Structural controls such as extensive jointing, and the wetting requirements of soils overlying various rock types may also play an important role. Figure 5 shows the rainfall intensity (in inches per hour) and the duration for several storms in the Blue Ridge of central Virginia where the resulting debris flows are known. The threshold line shown represents the minimum rainfall necessary for triggering debris

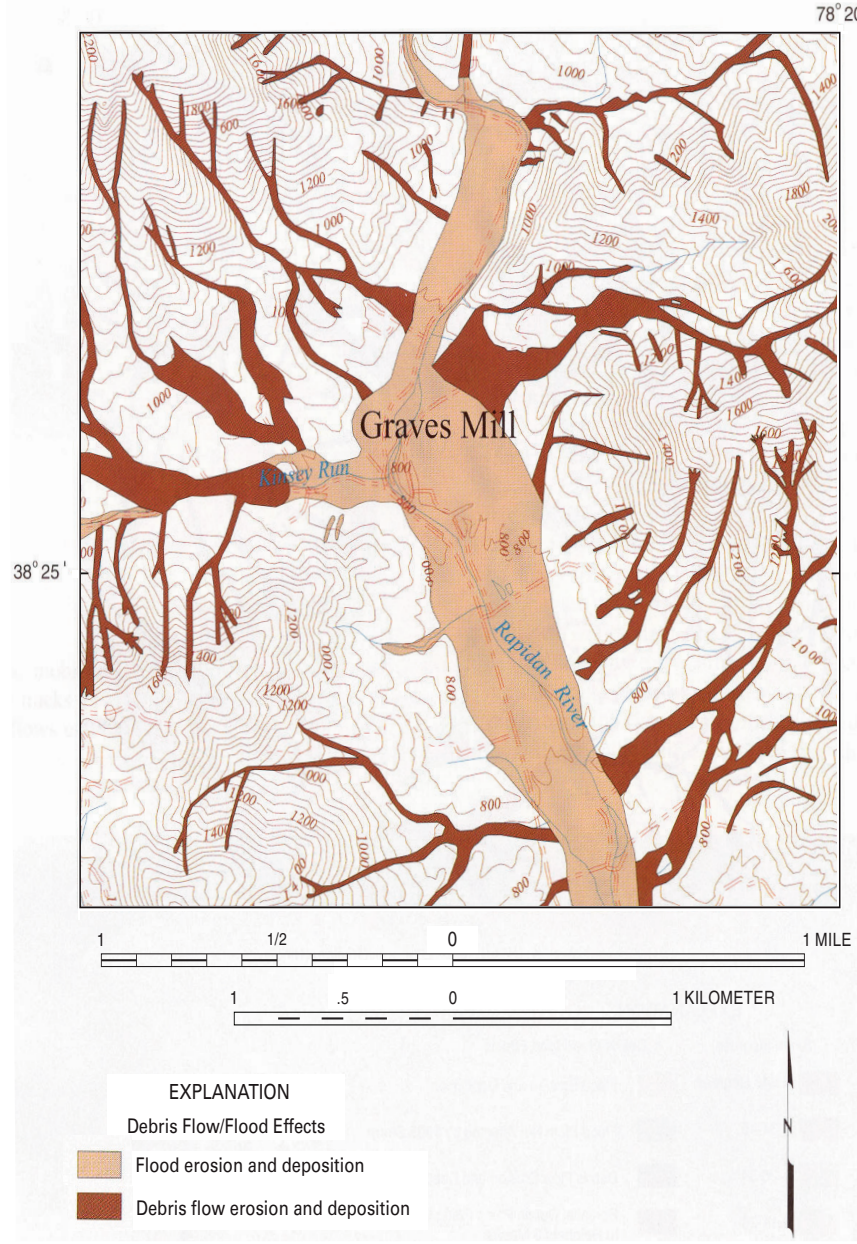

Figure 3. Map showing debris flows extending from an area of flooding within Madison County, Va., June 1995. flows. This threshold may be valid for the metamorphic igneous and sedimentary rocks of the Blue Ridge province, but may be entirely unreliable for the different rocks and soils of the Valley and Ridge and Appalachian Plateau provinces.

Mathematical formulas such as that applied for figure 5 may also be dependent on climatic factors of temperature and annual rainfall. For example, rainfall thresholds for triggering debris flows in areas such as California, Hawaii, and Puerto Rico are generally lower, suggesting the need to develop threshold models for each specific region in the United States that is prone to debris-flow activity.

Occurrence intervals of debris flows within a broad region can be estimated based on historical records as well as on

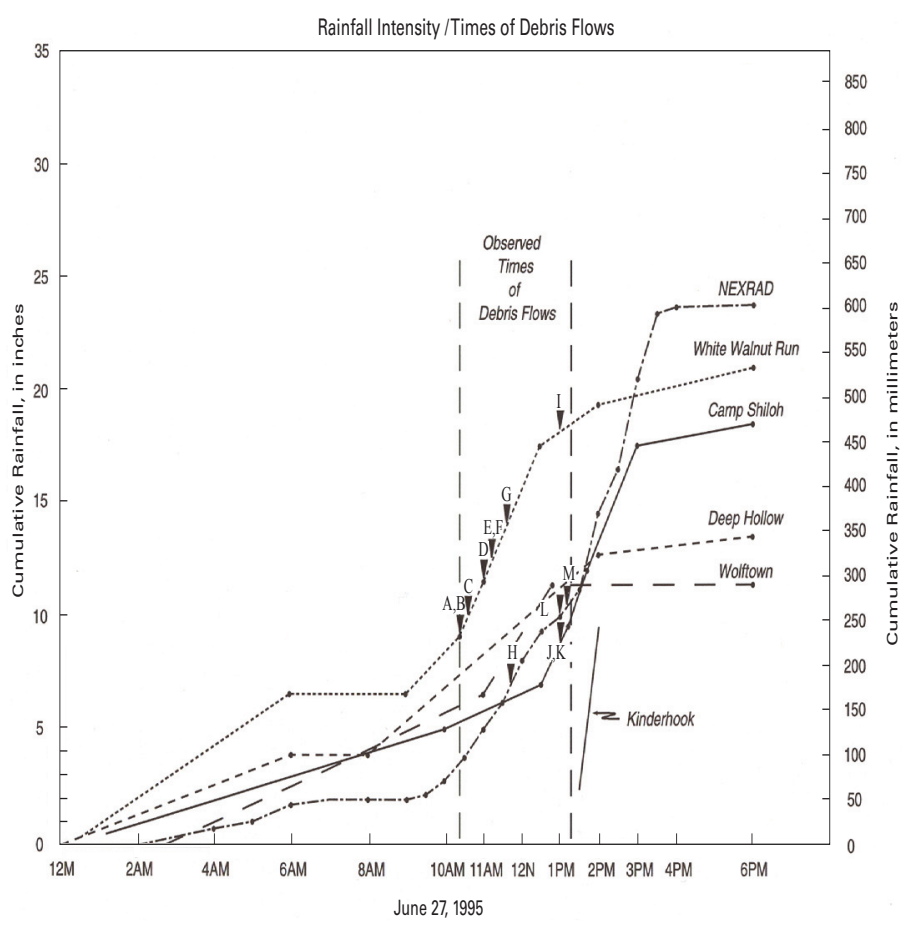

Figure 4. Rainfall and a few observed times of debris flows are shown as letters A-M during the June 27, 1995, storm in Madison County, Va. (Wieczorek and others, 2000). 


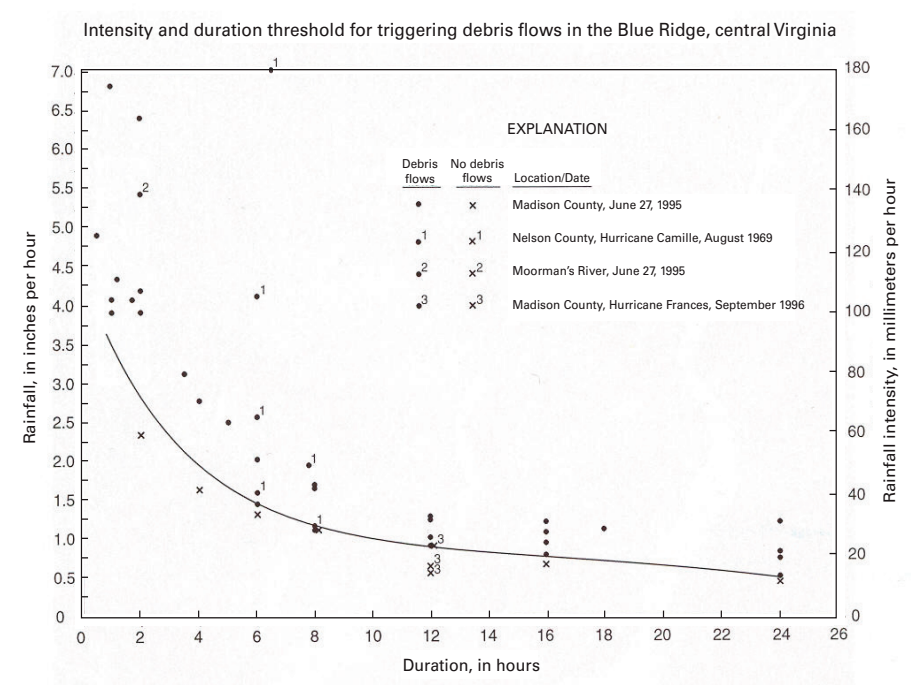

Figure 5. Rainfall intensity and duration for storms in the Blue Ridge of central Virginia. The line depicts a predicted threshold that represents minimum values necessary for triggering debris flows.

examination of prehistoric debris flows using carbon-14 dating. Within western and central Virginia, the recurrence interval for debris flows across the region has been estimated to be approximately 15 years. This estimate depends on the size of the area to which it is applied; the recurrence at a single locality or drainage basin is more likely in the order of thousands of years. Historical data suggest that the recurrence interval for debris flows is much higher in the southern Appalachian region of North Carolina and may be as frequent as 3 to 5 years.

Warning the public of potential or impending debris-flow hazards will require a concerted effort by local, State, and Federal Governments to inform the general public about these hazards. A network of rain gages that records rainfall in real time is available in parts of the southern and central Appalachian Mountains and could become more widely developed in the region. To be effective as a hazard-warning system, the raingage network data should be integrated with radar precipitation data, hillslope monitoring information, and radio, television, and Internet communications for State Emergency Response Centers and public and emergency managers in areas of concern. Longer range mitigation of debris-flow hazards can be improved by careful placement and strengthening of roads and bridges, and by the selection of sites for new construction that are away from areas most susceptible to landslide failure and subsequent inundation by debris flows.

\section{References Cited}

Campbell, R.H., 1975, Soil slips, debris flows, and rainstorms in the Santa Monica Mountains and vicinity, southern California: U.S. Geological Survey Professional Paper 851, 51 p.

Clark, M.G., 1987, Debris slide and debris flow historical events in the Appalachians south of the glacial border, Reviews in Engineering Geology, v. 7, p. 125-138.

Eaton, L.S., Morgan, B.A., Kochel, R.C., and Howard, A.D., 2003, Quaternary deposits and landscape evolution of the central Blue Ridge of Virginia: Geomorphology, v. 56, p. 139-154.
Radbruch-Hall, D.H., Colton, R.B., Davies, W.E., Lucchitta, I., Skipp, B.A., and Varnes, D.J., 1982, Landslide overview map of the conterminous United States: U.S. Geological Survey Professional Paper 1183, plate 1.

Wieczorek, G.F., Morgan, B.A., and Campbell, R.H., 2000, Debris-flow hazards in the Blue Ridge of central Virginia: Environmental and Engineering Geoscience, v. 6, n. 1, p. 3-23. Also available online at http://eeg.geoscienceworld.org/ cgi/content/abstract/6/1/3.

Williams, G.P., and Guy, H.P., 1973, Erosional and depositional aspects of Hurricane Camille in Virginia, 1969: U.S. Geological Survey Professional Paper 804, 80 p.

Wooten, R.M., Gillon, K.A., Witt, A.C., Latham, R.S., Douglas, T.J., Bauer, J.B., Fuemmeler, S.J., and Lee, L.G., 2008, Geologic, geomorphic, and meteorological aspects of debris flows triggered by Hurricanes Frances and Ivan during September 2004 in the Southern Appalachians of Macon County, North Carolina: Landslides, v. 5, no. 1, p. 31-44. Also available online at http://www.springerlink.com/ index/2705hw84480m5420.pdf.

\section{Where To Go for More Information}

1. The U.S. Geological Survey Landslide Program has information, publications, and educational information on its Web site at http://landslides.usgs.gov or call (toll-free) 1-800-654-4966

2. For general informtion about slides, debris flows, rock falls, or other types of landslides in your area, contact your city or county geology or planning office. In addition, all 50 States have State Geological Surveys that can be accessed through a link at the USGS Web site, at http://landslides. usgs.gov.

3. For an assessment of the landslide risk to an individual property or homesite, obtain the services of a State-licensed geotechnical engineer or engineering geologist. These professionals can be found through the membership listings of two professional societies, the American Society of Civil Engineers (ASCE), http://www.asce.org and the Association of Engineering Geologists, http://www.aegweb.org. Often, personnel in State or country planning or engineering departments can refer competent geotechnical engineers or engineering geologists.

4. For more information about the design and construction of debris-flow mitigation measures which may include debris basins, debris fences, deflection walls, or other protective works, consult your city or country engineer, local flood-control agency, or the U.S. Department of Agriculture, Natural Resources Conservation Service at http://www.ncgc.nrcs.usda.gov.

By Gerald F. Wieczorek and Benjamin A. Morgan 